\title{
Diabetic foot care plan
}

\author{
Gordon Dow MD FRCPC and The Diabetic Foot Care Plan Working Group*
}

\begin{abstract}
G Dow. Diabetic foot care plan. Can J Infect Dis 2000;11(Suppl D):15D-21D.
Diabetes mellitus is the number one cause of limb loss in North America, and is associated with growing, unacceptable rates of morbidity, mortality and economic loss. Approximately $80 \%$ of these amputations are preceded by the development of foot ulceration. Various disciplines have studied the prevention and management of foot ulceration in those with diabetes. The present care plan was constructed to incorporate the important contributions from these disciplines into practical therapeutic guidelines. The care plan has been divided into three basic sections: assessment, general management and antibiotic therapy. Each of these sections is described in detail and borrows heavily from previous Canadian position papers. Application of the care plan is illustrated by multiple diabetic foot clinical scenarios, which have been categorized according to the Wagner classification.
\end{abstract}

Key Words: Diabetes; Foot infection; Skin ulcer; Osteomyelitis

\section{Plan de soins pour le pied diabétique}

Le diabète sucré est la première cause d'amputation en Amérique du Nord et elle est associée à des taux inacceptables et croissants de morbidité, de mortalité et de perte de revenus. Environ 80 \% des amputations sont précédées d'un ulcère du pied. Diverses disciplines se sont penchées sur la prévention et le traitement de l'ulcère pédieux chez les patients atteints de diabète. Le présent plan de soins a été élaboré de façon à incorporer les importantes contributions de ces diverses disciplines aux directives thérapeutiques pratiques. Le plan de soins se subdivise en trois principales sections : évaluation, prise en charge générale et antibiothérapie. Chacune de ces sections est décrite en détails et emprunte largement aux énoncés de position canadiens antérieurs. L'application du plan de soins est illustrée par de multiples scénarios cliniques de pieds diabétiques qui ont été catégorisés selon les classifications de Wagner.

$\mathrm{P}$ eople with diabetes have a $15 \%$ lifetime risk of developing a foot ulcer and have an amputation rate of $6 / 1000$ people with diabetes/year (1). Recent data has suggested that $80 \%$ of foot ulcers and/or amputations can be prevented by daily foot examinations by the patient, foot care and appropriate footwear (2). Unfortunately, foot infection continues to be a pervasive problem for people with diabetes living in Canada, where the risk of amputation is 12 to 15 times that of the general population, and amputation is the most common cause of nontraumatic limb loss (3). This morbidity is compounded by the fact that of people with diabetes, $30 \%$ require amputation of the remaining limb at three years and $50 \%$ at four years after the first amputation (4). The mortality rate of diabetic amputees is also increased, with a three-year survival rate of $50 \%$ (5).

Extremity complications in people with diabetes are complex in their etiology and management, and hence do not fall under the purview of one specific medical discipline. The objective of the present paper, therefore, was to design a concise

Section of Infectious Diseases, Department of Internal Medicine, The Moncton Hospital, Moncton, New Brunswick

*Ms Sylvia Fournier, CHUM, Campus Hotel-Dieu, Montreal, Québec; Ms Lisa Huatkooper, St Boniface General Hospital, Winnipeg, Manitoba; Dr Tung Chuo Yang, Surrey Memorial Hospital, Surrey, British Columbia; Dr Omer Choudri, Memorial Hospital Bowmanville, Bowmanville, Ontario; Dr Shaun MacCormick, Department of Health, Truro, Nova Scotia; Mr Bud Jenkins, St John's Health Care Corporation, St John's, Newfoundland; Ms Marie-Claude Michel, Centre Hospital de l'Universite Laval, Ste Foy, Québec; Ms Chantel Bearden, Dufferin-Caledon Health Care Corporation, Orangeville, Ontario

Correspondence and reprints: Dr Gordon Dow, Section of Infectious Diseases, Department of Internal Medicine, The Moncton Hospital, 135 MacBeath Avenue, Moncton, New Brunswick E1C 6Z8. Telephone 541-857-5670, fax 541-857-5671 
COPYRIGHTPULSUSGROUP

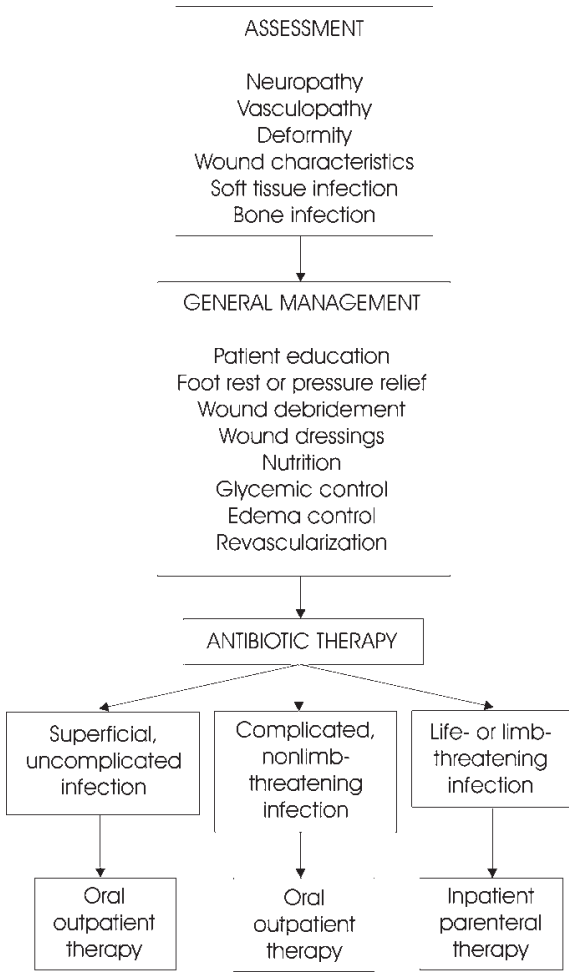

Figure 1) Diabetic foot infection care plan and straigntforwara care plan for the management of the diabetic foot using a multidisciplinary approach. The objective of this undertaking was not to provide a detailed review of the literature, as has been undertaken by several authors $(6,7)$, but rather to incorporate the current state of knowledge into a workable care plan. The care plan was organized as per the format in Figure 1, with sections discussing assessment of the diabetic foot (Table 1), general management based on the findings of that assessment (Table 2) and finally a description of empirical antibiotic therapy based on the severity of infection (Table 3). Where possible, photographic examples have been provided to illustrate various teaching points.

Empirical antibiotic therapy for diabetic foot infections has recently been reviewed $(8,9)$, and these guidelines have been incorporated into this care plan with only minor modifications (Table 3). The empirical antibiotic choice should be altered based on appropriate culture results, once obtained.

The present care plan has been further supplemented by management guidelines based on the Wagner Classification (Table 4). Previous research has indicated that the use of protocols based on the Wagner Classification may be associated with higher rates of ulcer healing (10).

This care plan was developed with the input of a multidisciplinary panel and is intended to function as a general guideline from which deviation can and should be made, based on the particular clinical problem at hand and the opinion of the health care team.

TABLE 1

Care plan for diabetic foot infections - Assessment

\begin{tabular}{lll}
\hline Pathology & Assessment & Photographic example \\
\hline Neuropathy & Consider significant if ulcer is painless, there is claw-toe deformity or \\
patient is unable to perceive $10 \mathrm{~g}$ Semmes-Weinstein monofilament
\end{tabular}

Testing for neuropathy with monofilament

Foot deformity - Presence of claw-toe deformity, prominent metatarsal heads and high arch (suggesting sensory motor neuropathy)

- Consider Charcot neuroarthropathy if there is evidence of polyarticular joint destruction; severe neuropathy with bounding pulses and venodilatation; one or more fractures unrelated to infection; midfoot plantar ulcer; or pes planus (loss of arch)

- Presence of midfoot eversion or inversion

- Assess adequacy of footwear

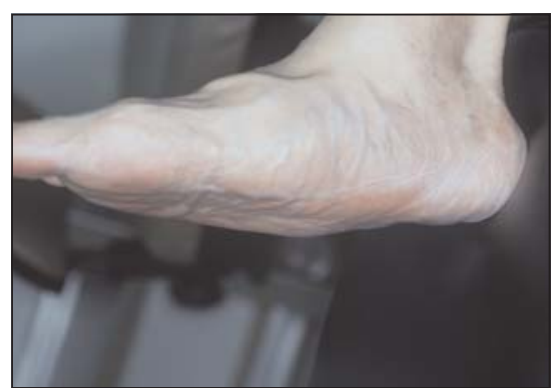

Charcot foot deformity with loss of plantar arch (pes planus) leading to 'rocker bottom' foot. Note typical superficial venous dilation of autonomic neuropathy 
TABLE 1 (continued)

\section{COPYRIGHT PULSUS GROUP INC, D DO NOT COPY}

\section{Care plan for diabetic foot infections - Assessment}

\section{Pathology}

Vasculopathy
Assessment

- Consider significant if pulses are absent and feet are cold, or if systolic pressure is $50 \mathrm{mmHg}$ or less at ankle or less than $30 \mathrm{mmHg}$ at toe using Doppler tests (note one-third of these patients will not heal unless perfusion is improved)

- Consider angiography if vasculopathy is present and there is severe claudication that is unacceptable to the patient, limb-threatening ischemia (progressive tissue necrosis) or ischemic leg or foot pain at rest or at night; patient is a surgical candidate; or angiography is not contraindicated (severe renal failure, anaphylaxis to contrast)

Wound

- Measure length, width and depth

- Classify wound bed as necrotic (yellow and/or black) or granulating (red)

- Classify ulcer according to the Wagner classification (see Table 4)

\section{Photographic example}

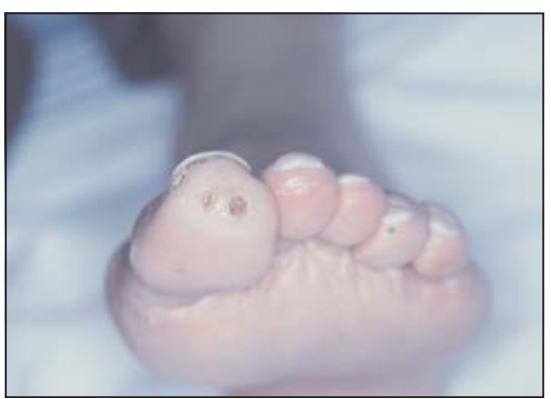

Ischemic foot with typical digital tip ulceration

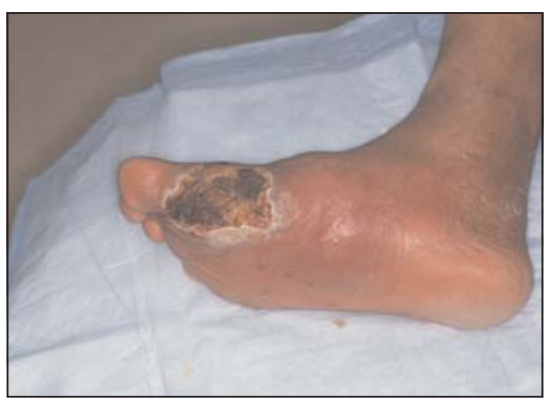

Necrotic 'black/yellow wound' requiring surgical debridement. Extensive cellulitis also present

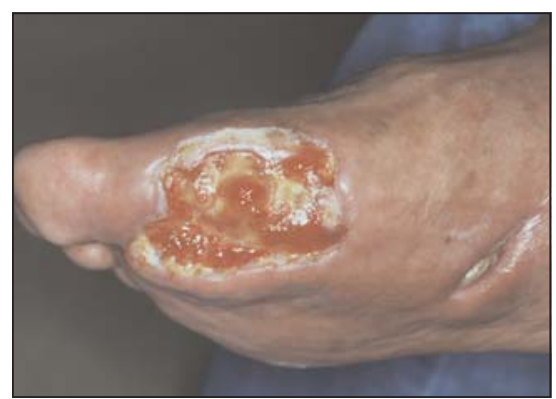

Conversion of wound $P_{4}$ to a 'red wound' (granulation tissue) after debridement and use of hydrogel dressings

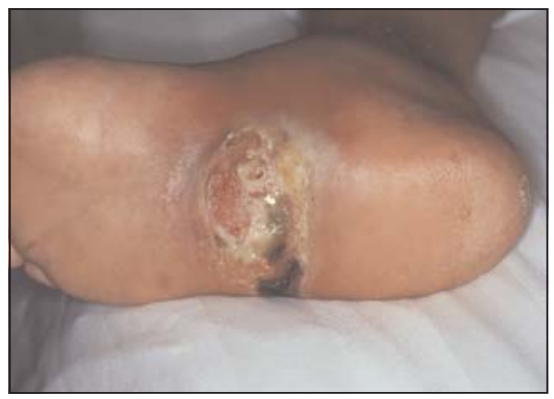

Infected Charest ulcer with spreading cellulitis
- Ulcers without inflammatory changes should not be cultured (unless patient is on immunosuppressive treatment or severe ischemia is present and infection is suspected)

- Technique: cleanse ulcer base vigorously with saline and obtain deep swab for aerobic (and anaerobic) culture; if abscess is present, aspirate and culture the fluid. Anaerobes are seldom present if ulcer is superficial and present for less than four to eight weeks

- Microbiology from a swab approximates a tissue biopsy and is adequate to guide antibiotic treatment $(11,12)$

- Osteomyelitis is diagnosed if there is visible bone or if bone is detected with a sterile probe; it is unlikely if ulcer is less than four weeks in duration (13)

- Serial x-rays should be performed to follow bone remodelling during treatment and to diagnose occult osteomyelitis

- Perform bone scan with or without gallium or white blood cell scan, only if serial x-rays are negative and osteomyelitis is strongly suspected (14)

- Assess infection severity (as per Table 3) 
TABLE 2

\section{Care plan for diabetic foot infections - Management}

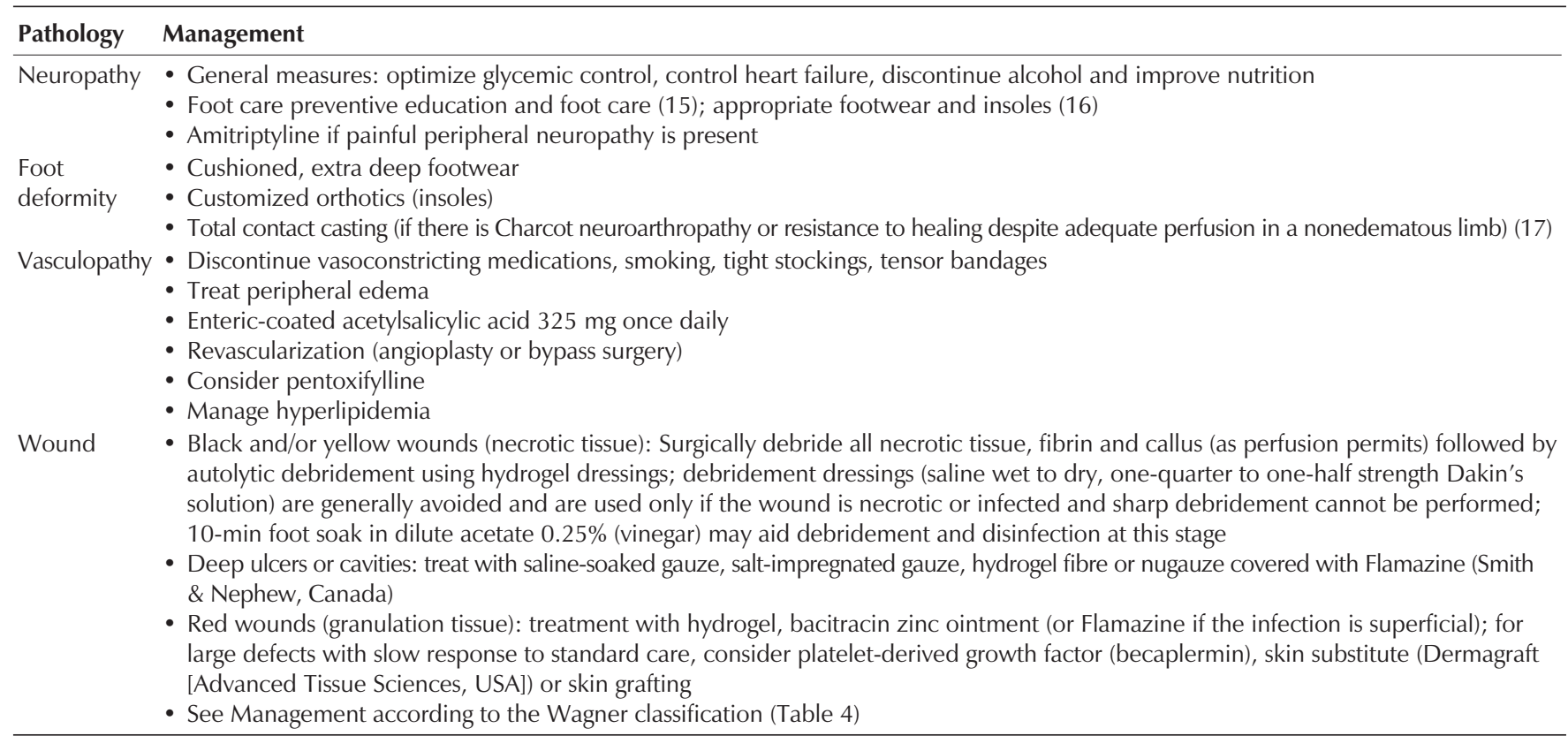

TABLE 3

Care plan for diabetic foot infections - Antibiotic therapy

\begin{tabular}{|c|c|c|c|}
\hline Infection & Patient characteristics & Organism coverage & Antibiotic, dose and duration \\
\hline $\begin{array}{l}\text { Superficial, } \\
\text { uncomplicated } \\
\text { infections }\end{array}$ & $\begin{array}{l}\text { - } 80 \% \text { of initial presentations } \\
\text { - One-month's duration or less } \\
\text { - } 2 \mathrm{~cm} \text { of inflammation or less } \\
\text { - Negative probe to bone } \\
\text { - Negative x-ray for osteomyelitis }\end{array}$ & $\begin{array}{l}\text { - Staphylococcus aureus } \\
\text { - Streptococcus species }\end{array}$ & $\begin{array}{l}\text { - Cephalexin } 500 \text { to } 1000 \mathrm{mg} \text { four times daily for } 14 \text { days, or } \\
\text { - Cotrimoxazole } 160 / 800 \mathrm{mg} \text { bid for } 14 \text { days, or } \\
\text { - Amoxicillin/clavulanate 500/125 mg tid for } 14 \text { days, or } \\
\text { - If patient is penicillin allergic, clindamycin } 300 \mathrm{mg} \text { tid for } \\
14 \text { days }\end{array}$ \\
\hline $\begin{array}{l}\text { Complicated, } \\
\text { nonlimb- } \\
\text { threatening } \\
\text { infections }\end{array}$ & $\begin{array}{l}\text { - } 20 \% \text { of infections } \\
\text { - Acute aggressive infections } \\
\text { - Chronic progressive infections } \\
\text { - Greater than } 2 \mathrm{~cm} \text { of cellulitis } \\
\text { - Involve deep soft tissue } \\
\text { - Involve bones or joints } \\
\text { - Require outpatient management } \\
\text { - Occasionally require home IV therapy } \\
\text { or inpatient management }\end{array}$ & $\begin{array}{l}\text { - S aureus } \\
\text { - Streptococcus species } \\
\text { - Anaerobes } \\
\text { - Coliforms (enteric } \\
\text { Gram-negative bacilli) }\end{array}$ & $\begin{array}{l}\text { - Treatment duration: } 14 \text { days for soft tissue infections; } \\
\text { average of } 12 \text { weeks for osteomyelitis }(18,19) \\
\text { - Cephalexin } 500 \text { to } 1000 \mathrm{mg} \text { four times daily plus } \\
\text { Metronidazole } 500 \mathrm{mg} \text { bid, or } \\
\text { - Cotrimoxazole } 160 / 800 \text { to } 320 / 1600 \mathrm{mg} \text { bid plus } \\
\text { Metronidazole } 500 \mathrm{mg} \text { bid, or } \\
\text { - Amoxicillin/clavulanate } 500 / 125 \mathrm{mg} \text { tid, or } \\
\text { - Cotrimoxazole } 160 / 800 \text { to } 320 / 1600 \mathrm{mg} \text { bid plus } \\
\text { Clindamycin } 300 \mathrm{mg} \text { four times daily, or } \\
\text { - Clindamycin } 300 \mathrm{mg} \text { four times daily plus ciprofloxacin } \\
500 \text { mg bid }\end{array}$ \\
\hline \multirow[t]{2}{*}{$\begin{array}{l}\text { Limb- and life- } \\
\text { threatening } \\
\text { infections }\end{array}$} & $\begin{array}{l}\text { - Acutely evolving infections } \\
\text { - Involve sepsis } \\
\text { - Involve bacteremia } \\
\text { - Require inpatient management } \\
\text { including surgical intervention if } \\
\text { necessary } \\
\text { - Occasionally require home IV therapy } \\
\text { postdischarge }\end{array}$ & $\begin{array}{l}\text { - S aureus } \\
\text { - Streptococcus species } \\
\text { - Anaerobes } \\
\text { - Coliforms (enteric Gram- } \\
\text { negative bacilli) } \\
\text { - Add aminoglycoside for } 48 \\
\text { to } 72 \text { h pending cultures } \\
\text { - If infection is hospital- } \\
\text { acquired, Gram-negative } \\
\text { bacilli are suspected }\end{array}$ & $\begin{array}{l}\text { - Treatment durations as per complicated } \\
\text { nonlimb-threatening infection } \\
\text { - Intravenous cefriaxone } 1 \mathrm{~g} \text { every } 24 \mathrm{~h} \text { plus either IV } \\
\text { metronidazole } 500 \mathrm{mg} \text { every } 12 \mathrm{~h} \text { or IV clindamycin } \\
600 \mathrm{mg} \text { every } 8 \mathrm{~h} \text {, or } \\
\text { - IV cefotaxime } 1 \mathrm{~g} \text { every } 8 \mathrm{~h} \text {, plus either IV metronidazole } \\
500 \mathrm{mg} \text { every } 12 \mathrm{~h} \text { or IV clindamycin } 600 \text { mg every } 8 \mathrm{~h}\end{array}$ \\
\hline & & $\begin{array}{l}\text { - Broad spectrum coverage } \\
\text { including antipseudomonal } \\
\text { coverage } \\
\text { - Add aminoglycoside for } 48 \\
\text { to } 72 \text { h pending cultures }\end{array}$ & $\begin{array}{l}\text { - Intravenous piperacillin/tazobactam } 4.5 \text { g every } 8 \mathrm{~h} \text { or } \\
3.375 \text { g every } 6 \mathrm{~h} \text {, or } \\
\text { - Intravenous ceftazidime } 1 \text { to } 2 \text { g every } 8 \mathrm{~h} \text { plus IV } \\
\text { clindamycin } 600 \mathrm{mg} \text { every } 8 \mathrm{~h} \text {, or } \\
\text { - Intravenous imipenem/cilastatin } 500 / 500 \mathrm{mg} \text { every } 6 \mathrm{~h}\end{array}$ \\
\hline
\end{tabular}

IV Intravenous. Table adapted from reference 8 
TABLE 4 COPYRIGHT PULSUS GROUP ING. " DO NOT COPY

Management according to the Wagner classification

\begin{tabular}{lll}
\hline Grade & Description & Management \\
\hline 0 & High risk foot based on & - Assess for neuropathy and vasculopathy (see Table 1) \\
neuropathy, vasculopathy & - Provide foot care education \\
or deformity; no ulcer & - Provide emollients for dry skin \\
present & - Pare callouses, trim nails, consider referral to podiatry \\
& - Provide appropriate foot wear and orthotics based \\
& on degree of foot deformity (see Table 1) \\
& - If there is severe claudication or ischemic rest pain, \\
& refer for vascular surgery \\
& - For less severe vascular disease or nonsurgical \\
& candidates, consider medical vascular management \\
& (see Table 2)
\end{tabular}

Superficial ulcer that does not penetrate into subcutaneous tissue
- Management as per grade 0

- Surgically debride all necrotic (black and/or yellow) tissue and callous as perfusion permits (consider chemical or enzymatic debridement if sharp debridement is not possible)

- Follow sharp debridement by the use of topical hydrogel to permit autolytic debridement and granulation

- Cleanse with saline between dressing changes

- Manage infection as per Tables 1 and 2

- Provide pressure relief (eg, crutches, walkers, wheelchairs, healing sandals, air casts, total contact casts and extra deep footwear or orthotics)

\section{- Management as per grade 1}

ulceration with penetration into subcutaneous tissue but not other deep structures

\section{Photographic illustration}

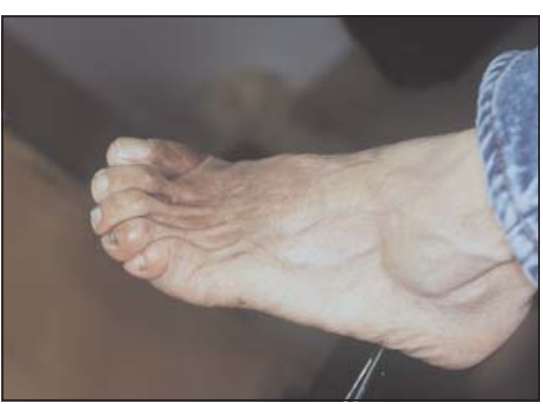

Sensory motor neuropathy producing contractions of instrinsic muscles offoot leading to claw-toe deformity

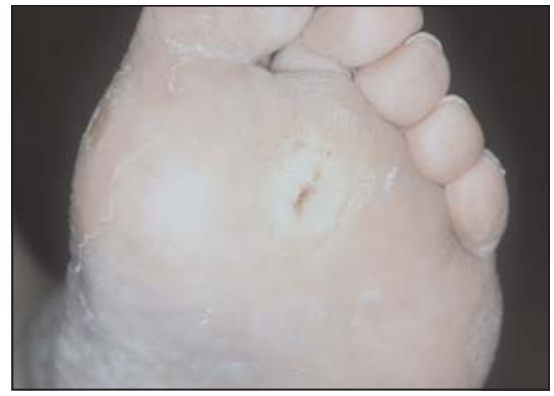

Superficial neuropathic plantar ulcer of forefoot

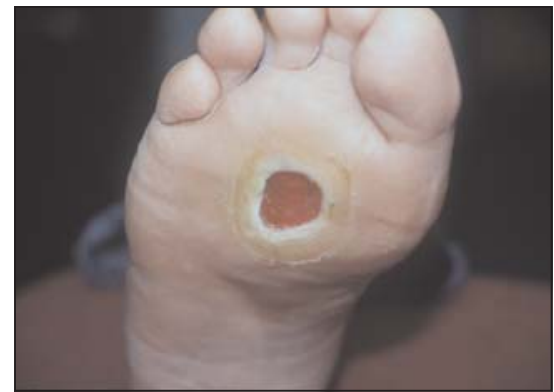

Neuropathic plantar forefoot ulcer extending into subcutaneous tissue

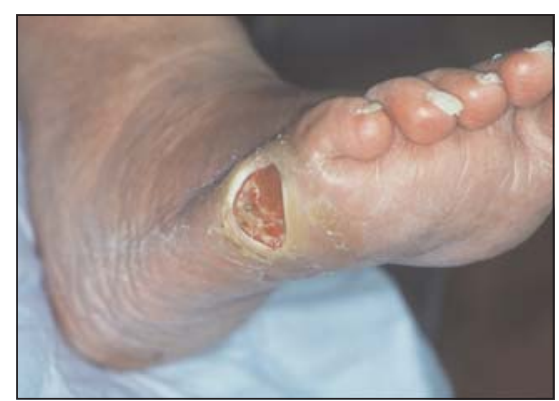

Deep neuropathic-ischemic ulcer extending into the fifth metatarsal bone 
TABLE 4 (continued)

\section{3}

Grade
Localized gangrene of toe, forefoot or heel
Management

- Management as per grade 3

- Lesions in this class are often ischemic, and vascular assessment is critical

- Gangrenous toes may be allowed to petrify and autoamputate; may be the safest option where surgical wounding of ischemic tissue is not well tolerated (unless reperfusion is performed). In the setting of ischemia, aggressive surgical debridement may lead to further tissue loss; $0.25 \%$ vinegar soaks for 10 min daily and chemical or enzymatic debridement (especially of heel necrosis) may be preferable

- $0.25 \%$ vinegar foot soaks appear to prevent progression from dry to wet gangrene if focal dry gangrene is present (mix 1 tablespoon of vinegar per cup of warm tap water)

- Refer for amputation
Photographic illustration

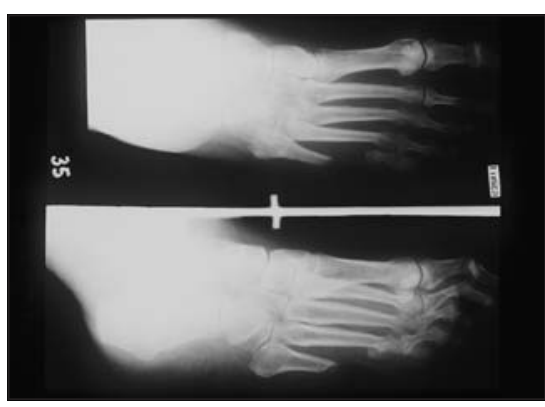

Radiographic bone destruction of fifth metatarsal

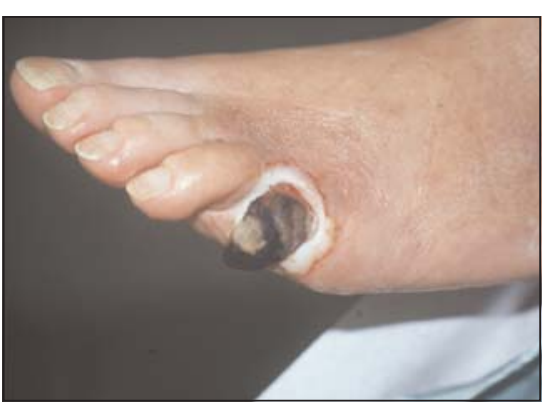

Gangrene of single digit (ischemic)

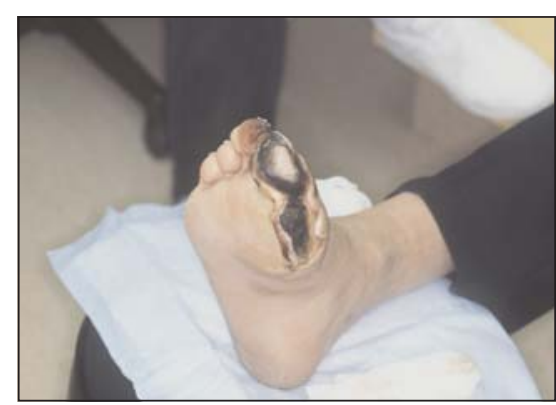

Extensive dry gangrene of forefoot

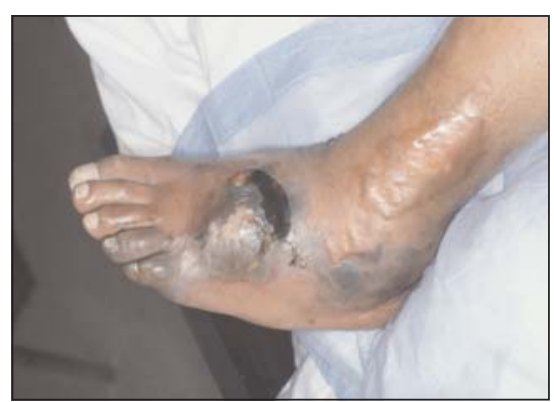

Extensive necrotizing fasciitis leading to gangrene of whole foot 


\section{REFERENCES}

\section{COPYRIGHT PULSUS GROUP INC, D DO NOT COPY}

1. Most RS, Sinnock P. The epidemiology of lower extremity amputations in diabetic individuals. Diabetes Care 1983;6:87-91.

2. Edmonds ME, Blundell MP, Morris HE, Thomas EM, Cotton LT, Watkins PJ. The diabetic foot: Impact of a foot clinic. Q J Med 1986;232:763-71.

3. Lawee D, Csima A. Diabetes-related lower extremity amputations in Ontario: 1987-88 experience. Can J Pub Health 1992;83:298-302.

4. Ebskov B, Josephsen P. Incidence of amputation and death after gangrene of the lower extremity. Prosthet Orthot Int 1980;4:77-80.

5. Palumbo PJ, Melton LJ. Peripheral vascular disease and diabetes. In: Diabetes in America: Diabetes Data Compiled 1984. Washington, DC: US Government Printing Office, 1985:1-21.

6. Caputo G, Cavanagh PI, Ulbrecht J, Gibbons G, Karchaner A. Assessment and management of foot disease in patients with diabetes. N Engl J Med 1994;331:854-60.

7. Lipsky BA, Pecoraro RE, Wheat LJ. The diabetic foot: soft tissue and bone infection. Infect Dis Clin North Am 1990;4:409-32.

8. Harding G, Field S, MacMahon R, Louie T, and the Prairie Consensus Conference Group. The antibiotic puzzle: Guidelines for the family physician. Can J Infect Dis 1997;8(Suppl C):2C-16C.

9. Fong IW and the Committee on Antimicrobial Agents. Management of diabetic foot infection: A position paper. Can J Infect Dis 1996; 7:361-5.

10. Calhoon J, Cantrell J, Cobos J, et al. Treatment of diabetic foot infections: Wagner Classification, therapy and outcome. Foot Ankle 1988:9:101-6.

11. Sapico Fl, Witte JL, Canawati HN, Montgomerie JZ, Bessman AN. The infected foot of the diabetic patient: quantitative microbiology and analysis of clinical features. Rev Infect Dis 1984;6(Suppl 1):S171-6.

12. Wheat LJ, Allen SD, Henry M, et al. Diabetic foot infections: bacteriologic analysis. Arch Intern Med 1986;146:1935-40.

13. Grayson ML, Balogh K, Levin E, Karchmer AW. "Probing to bone" - a useful clinical sign of osteomyelitis in diabetic fetid feet. $30^{\text {th }}$ Interscience Conference on Antimicrobial Agents and Chemotherapy, Atlanta, October 21-21, 1990. (Abst)

14. Newman LG, Waller J, Palestro CJ, et al. Unsuspected osteomyelitis in diabetic foot ulcers: diagnosis and monitoring by leukocyte scanning with indium in 111 oxyquinoline. JAMA 1991;266:1246-51.

15. Young MJ, Cavanagh PR, Thomas G, Johnson MM, Murray H, Boulton AJM. The effect of callus removal on dynamic plantar foot pressures in diabetic patients. Diabet Med 1992;9:55-7.

16. Soulier SM. The use of running shoes in the prevention of plantar diabetic ulcers. J Am Podiatr Med Assoc 1986;76:395-400.

17. Mueller MJ, Diamond JE, Sinacore DR, et al. Total contact casting in treatment of diabetic plantar ulcers: controlled clinical trial. Diabetes Care 1989;12:384-8.

18. Peterson LR, Lissack LM, Canter K, et al. Therapy of lower extremity infections with ciprofloxacin in patients with diabetes mellitus, peripheral vascular disease, or both. Am J Med 1989;86:801-8.

19. Bamberger DM, Daus GP, Gerding DN. Osteomyelitis in the feet of diabetic patients: long-term results, prognostic factors, and the role of antimicrobial and surgical therapy. Am J Med 1987;83:653-60.

20. Dow G, Thompson W, Brunham R, et al. Duration of antimicrobial therapy for diabetic foot osteomyelitis. Clin Invest Med 1994;17(Suppl):Abst 440. 


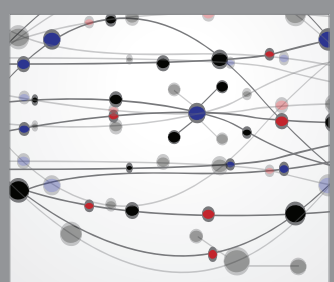

The Scientific World Journal
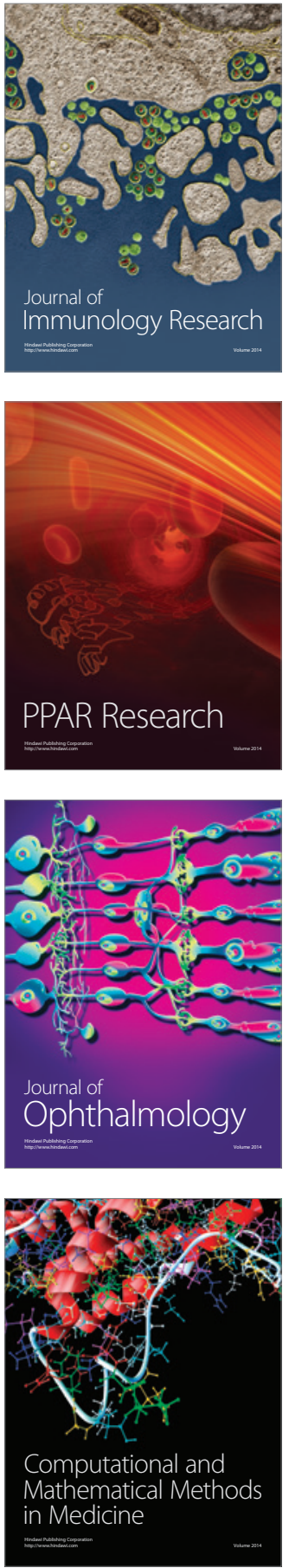

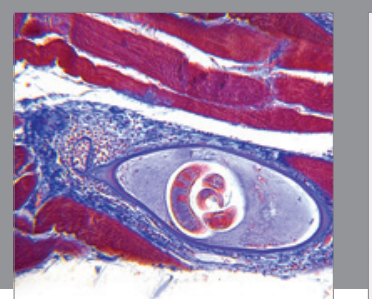

Gastroenterology Research and Practice

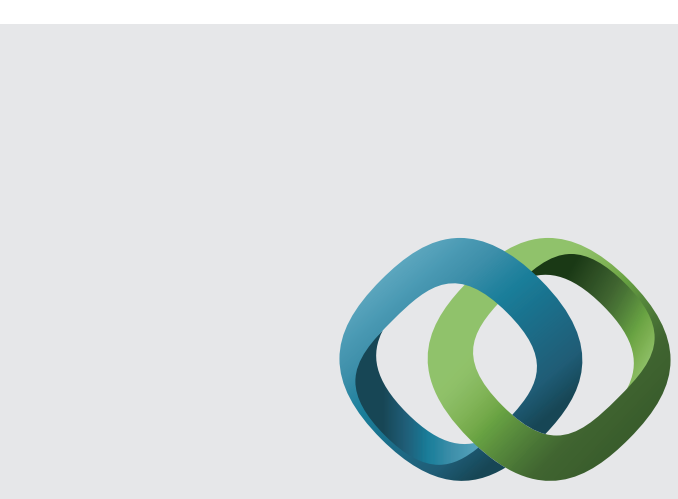

\section{Hindawi}

Submit your manuscripts at

http://www.hindawi.com
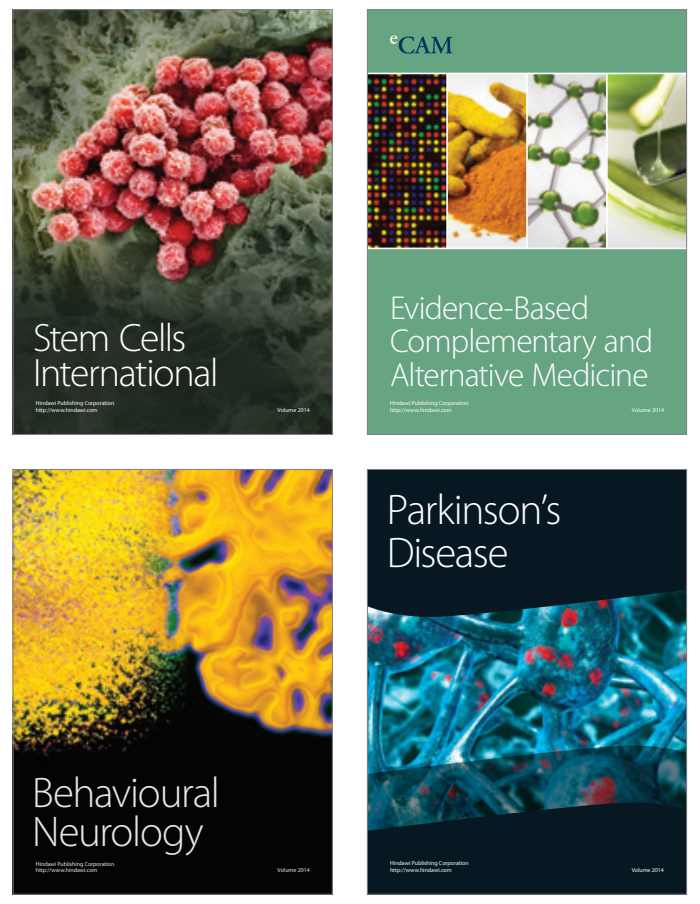
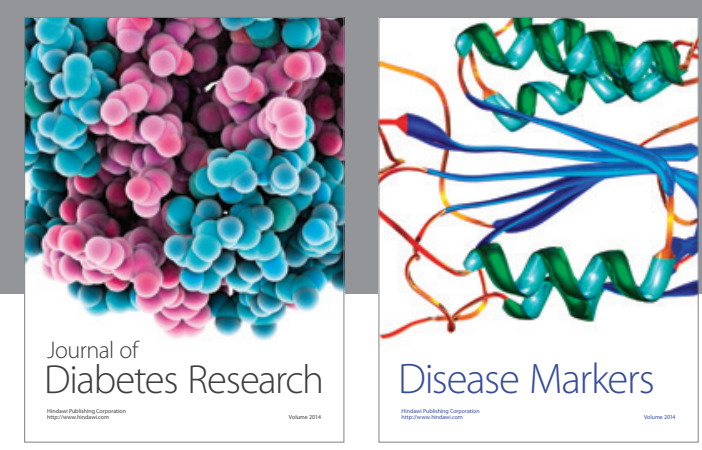

Disease Markers
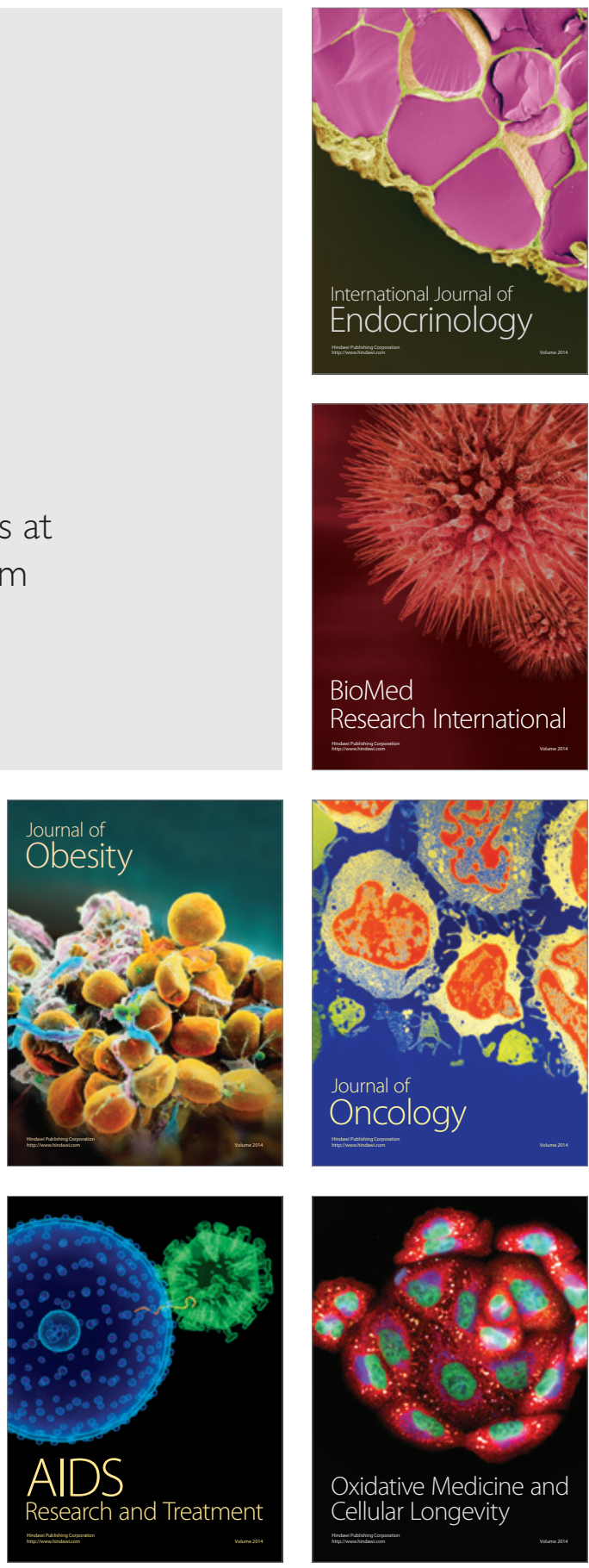